Original article

\title{
Seeking markers to distinguish HCV-infected-autoimmune subjects from uninfected-autoimmune patients
}

\author{
Amany S. Maghraby, Solaf A. Kamel, Dalia B. Fayed, Heba Shawky, Mona A. Razin, Rola N. Abd-Elshafy, Azza F. \\ Arafa, Dina N. Abd-Elshafy, Mahmoud M. Bahgat \\ The National Research Centre, Cairo, Egypt
}

Received 10 October 2018, Revised 1 May 2019, Accepted 8 August 2019

(C) 2018, Maghraby A.S., Kamel S.A., Fayed D.B., Shawky H., Razin M.A., Abd-Elshafy R.N., Arafa F.A., Abd-Elshafy D.N., Bahgat M.M. (C) 2018, Russian Open Medical Journal

\begin{abstract}
Introduction - Egypt has the highest prevalence of hepatitis C virus (HCV) infection which is reported to be associated with autoimmune manifestations.

Aim - There is a need for markers that enable differentiation between viral and non-infected-autoimmune patients.

Material and Methods - Levels of the B-cell activation factor (BAFF), IL6, IL10 and TNF- $\alpha$ were quantified by ELISA in sera from HCVinfected-autoimmune patients (HCV-Al), HCV-infected patients with no autoimmune diseases (HCV-NAI), non-infected autoimmune patients (NIAI) and healthy control humans (C).

Results - HCV-infected patients were 12.96, 8.33, 69.44 and $36.11 \%$ positive for the auto-antibodies ANA, AMA, ASMA and AGPCA respectively. The BAFF level was significantly $(P<0.05)$ higher among the NI-Al patients compared to the HCV-NAI, HCV-AI patients and healthy control humans (C). For the IL6, no significant differences were seen between various patients' groups. In case of the IL10, its' levels were significantly higher $(P<0.05)$ in the HCV-Al, NI-Al and HCV-NAl patients in comparison to the C humans. Levels of TNF- $\alpha$ were significantly $(P<0.001$ and 0.0001$)$ higher amongst the HCV-NAI and HCV-Al than in the NI-Al patients respectively. Also, levels of the TNF- $\alpha$ were significantly $(P<0.0001)$ higher amongst the $\mathrm{C}$ compared to the NI-Al. Levels of TNF- $\alpha$ were not significant amongst the HCV-NAI and HCV-Al patients than in $\mathrm{C}$ subjects.

Conclusion - The obtained results showed that both IL6 and BAFF can serve as markers for autoimmunity and/or autoimmunity resulting from severe HCV infection, whereas, IL10 and TNF- $\alpha$ can be considered as markers for HCV infection in Egypt (genotype is mostly 4a).
\end{abstract}

Keywords: Autoimmunity, B-cell activation factor, hepatitis C virus, IL10, TNF- $\alpha$

Cite as Maghraby AS, Kamel SA, Fayed DB, Shawky H, Razin MA, Abd-Elshafy RN, Azza FA, Abd-Elshafy DN, Bahgat MM. Seeking markers to distinguish HCVInfected-autoimmune subjects from uninfected-autoimmune patients. Russian Open Medical Journal 2019; 8: e0308.

Correspondence to Amany Sayed Maghraby. Department of Therapeutic Chemistry, Division of Pharmaceutical and Drug Industries Research and Research Group Immune- and Bio-markers for Infection, the Centre of Excellence for Advanced Sciences, the National Research Centre, Cairo, Egypt. Fax: 002033371718. E-mail: as.maghraby@nrc.sci.eg. Phone: 00201226489703.

\section{Introduction}

Egypt has the highest prevalence of HCV infection (14.7\%) worldwide [1] where the prevailing genotype (90\%) is mostly 4a [2, 3]. An Egyptian study compared HCV prevalence in 2015 with a national survey made in 2008; results demonstrated $\sim 29 \%$ reduction in HCV RNA prevalence and added that approximately 3.7 million persons are chronically infected with HCV in the age group between 15-59 years [4]. The drop in HCV prevalence between the two reports could be attributed to the national control efforts or due to significant reduction in the prevalence of human schistosomiasis, a parasitic disease whose infection is thought to be highly related to HCV infections [4, 5].

It was reported that a total of $40-74 \%$ of $\mathrm{HCV}$ infected patients may experience immunological complications during the course of the disease $[6,7]$. Autoimmunity is a break in self-tolerance involving stimulation of auto-antibodies producing self-reactive B cells and formation of complement-fixing immune complexes ending by tissue damage [8].

Infection by HCV was reported to be associated with various autoimmune manifestations [9]. In addition to the liver, HCV may exist in other tissues such as kidney, skin and salivary glands [10]. Such tissues may represent reservoirs for the virus and contribute to both persistence and viral reactivation [10]. It was postulated that replication and expression of $\mathrm{HCV}$ antigens in chronically $\mathrm{HCV}$ infected patients in these tissues may play a role in development of autoimmune manifestations [10]. Some autoimmune diseases were reported in Egypt like rheumatoid arthritis with prevalence of $21 \%$, [11] autoimmune hepatitis with prevalence of 32\% [5] and diabetes with prevalence of $12.6 \%$ in Egypt under age of 15 [12].

Rheumatic diseases, arthralgia, arthritis, vasculitis, sicca syndrome, myalgia, and fibromyalgia are examples for inflammatory and autoimmune reactions associating HCV infection [13]. The 
mechanism by which HCV triggers autoimmune reactions and production of auto-antibodies was attributed to expansion of $\mathrm{CD5}^{+}$ subpopulation and over-expression of CD81 in the peripheral Bcells from chronically infected patients in response to increase of HCV viral load [14]. The same authors demonstrated positive correlation between auto-antibodies with both cirrhosis and age and postulated that titer and type of such auto-antibodies might help in diagnosis and treatment of infection.

Cytokines were frequently reported as markers for both HCV infection $[15,16]$ and autoimmune diseases [17, 18]. Contradictory results were published on levels of IL6 among HCV infected humans. While some demonstrated its decrease upon infection, [19] others showed its increase [15, 16, 20]. Interestingly, a study concluded IL6 as valuable markers for severity of HCV infection as its serum levels were higher among patients presenting severe infection compared to milder ones and also patients with genotype 1 showed higher serum levels of IL- 6 than those with genotype 2 [21].

A study on Egyptian patients' demonstrated higher serum IL10 and TNF- $\alpha$ levels compared to non-infected control [15, 16, 22]. B cell activating factor (BAFF) is essential in B lymphocytes development, maturation and activation [23]. Cytokines, such as IFNs and IL-10 activate myeloid cells including macrophages and dendritic cells to produce BAFF [23]. Increased BAFF stabilizes auto-reactive $B$ cells leading to autoimmune pathogenesis [23]. Supportively, Egyptian juvenile idiopathic arthritis patients had significantly higher levels of BAFF that correlated with both clinical manifestations and disease activity [24]. The interrelationship between BAFF and HCV infection emerges from the capacity of virus to induce multiple $B$ cell disorders while developing chronicity [25]. In concordance, an increasing association was found between BAFF-871C/T promoter polymorphism and HCVrelated mixed cryoglobulinemia [26].

Apart from HCV infection, cytokines were also reported as useful markers in several autoimmune diseases. Secretion of IL-6 and TNF- $\alpha$ was promoted among juvenile idiopathic arthritis patients [17]. IL-6 production was shown to be significantly higher among neuromyelitis optica patients compared to healthy humans [27].

Altogether highlights importance of monitoring autoimmmune pathogensis among HCV infected humans which will enable early discovery and hence treatment of the onset of the autoimmune manifestation. Alternatively, it will be of great relevance to study the susceptibility of autoimmune patients to HCV infection. Supportively, it was reported that an autoimmune disease known as membranoproliferative glomerulonephritis (MPGN) was treatable upon anti-HCV therapy [28].

Therefore, a primary aim of the work was to investigate the influence of autoimmune pathogenesis on HCV-load among Egyptian patients. A second major objective was to investigate any potential differential regulation of several immune markers namely BAFF, IL6, IL10 and TNF- $\alpha$ amongst HCV-infectedautoimmune Egyptian patients, HCV-infected Egyptian patients presenting no autoimmune diseases and non-infected autoimmune patients hoping to identify a marker which can distinguish between the three groups. Last aim upon identifying such marker(s) was to introduce a recommendation of frequent screening of Egyptian patients presenting autoimmune disease for active $\mathrm{HCV}$ infection and vice versa.

\section{Material and Methods}

\section{Subjects and experimental design}

The study involved 68 Egyptian subjects who were divided into 4 groups. Group (1): 10 healthy subjects. Fifty HCV infected patient's candidates for interferon therapy (direct-acting antiviral for the treatment of HCV-infection-DAAS; were not available in Egypt at the time of collected samples from 2012 to 2014) were divided into group 2 and 3 according to the positivity of the immunodiagnostic tests to detect autoimmune antibodies. Twenty-seven HCV infected patients were negative for the diagnostic test of auto-immune antibodies (HCV-NAI) and considered as group (2). Twenty-three HCV infected patients were positive for the diagnostic test of auto-immune antibodies (HCVAl) and considered as group (3). Eight patients were positive for autoimmune antibodies and negative for HCV diagnosis (AI) and considered as group (4): Whole blood samples were collected from all subjects. Serum was separated, divided into aliquots and stored at $-80^{\circ} \mathrm{C}$ until being used.

\section{Detection of viral load by Real-Time PCR (qrtPCR)}

HCV-RNA was quantitatively detected in sera by the Abbott real time HCV Kit (Abbott Molecular Inc; Des Plaines, IL 60018 USA) which uses RT-PCR conjugated with real time fluorescent. The assay is standardized against the second WHO international standard for HCV-RNA (NIBSC Code 96\798) and results are reported in IU $\backslash \mathrm{mL}$ [29].

\section{Detection of liver enzymes and a1-fetoprotein (AFP)}

Liver complications due to viral infection were biochemically assessed by quantifying liver enzymes and AFP. The quantitative determinations of both the aspartate aminotransferase/glutamate oxaloacetate trasaminase, (ASAT\GOT) and alanine aminotranferase \glutamate pyruvate transaminase, (ALAT\GPT) were carried out according to the manufacture instructions (Roche automated clinical chemistry analyzers, cobas ${ }^{\circledR}$, City, Country). AFP assay was performed according to the manufacturer instructions (Roche; cobas $^{\circledR}$, Hitachi, Japan). assay

Detection of auto-antibodies by indirect immunofluorescence

The indirect immunofluorescent assay was performed on slides mounted with mouse tissues (kidney, liver and stomach) to test presence of auto-antibodies in sera namely anti-nuclear antibodies (ANA), anti-smooth muscle antibodies (ASMA) and antimitochondrial antibodies (AMA). Serum samples were diluted in phosphate buffer saline (PBS). A FITC-labeled polyclonal rabbit anti-human-IgG was used for fluorescence visualization of the autoimmune reactions. On each tested slide, a negative control (IFA System Negative Control; INOVA Diagnostics, San Diego CA USA) was included.

Quantification of cytokines and BAFF in patients' sera by enzyme-linked immunosorbent assay (ELISA)

Levels of IL-6, IL-10 and TNF- $\alpha$ in patients' sera were detected by ELISA using reagent kits from (KOMA BIOTECH INC.; Seoul, Korea). The changes in the optical densities (OD) were recorded at $\lambda$-max $450 \mathrm{~nm}$ using a multi-well plate reader (Tecan; Sunrise, Austria, $\mathrm{GmbH}$ ). The concentrations of IL-6, IL-10 and TNF- $\alpha$ were calculated according to equations of the experimental standard curves. 


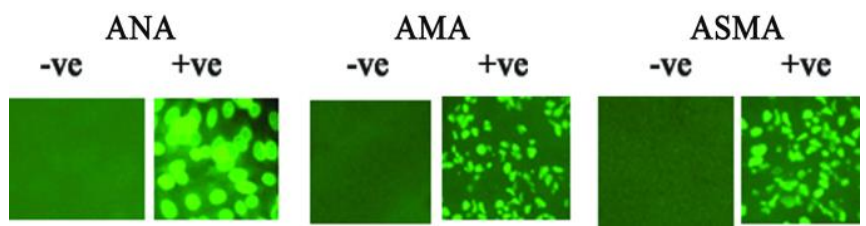

Figure 1. Detection of autoimmune antibodies using indirect immune fluorescent assay. ANA (anti-nuclear antibodies), ASMA (anti-smooth muscle antibodies), AMA (anti-mitochondrial antibodies) (X40).
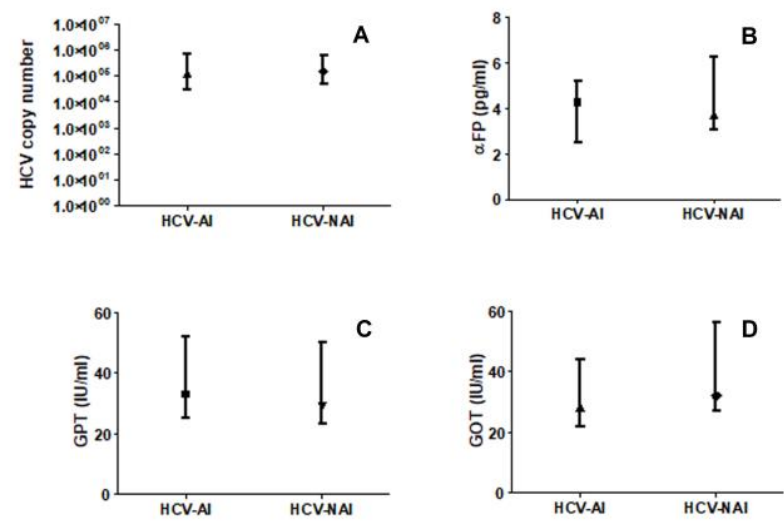

Figure 2. HCV load (A), levels of $\alpha F P$ (B) and liver enzymes (C\&D) among HCV-infected-autoimmune (HCV-Al) patients and HCV-infectednon autoimmune (HCV-NAI) patients. Figure was in box-plot form.
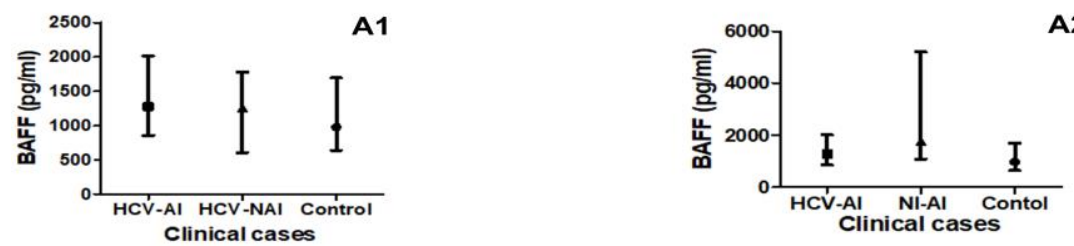

A2
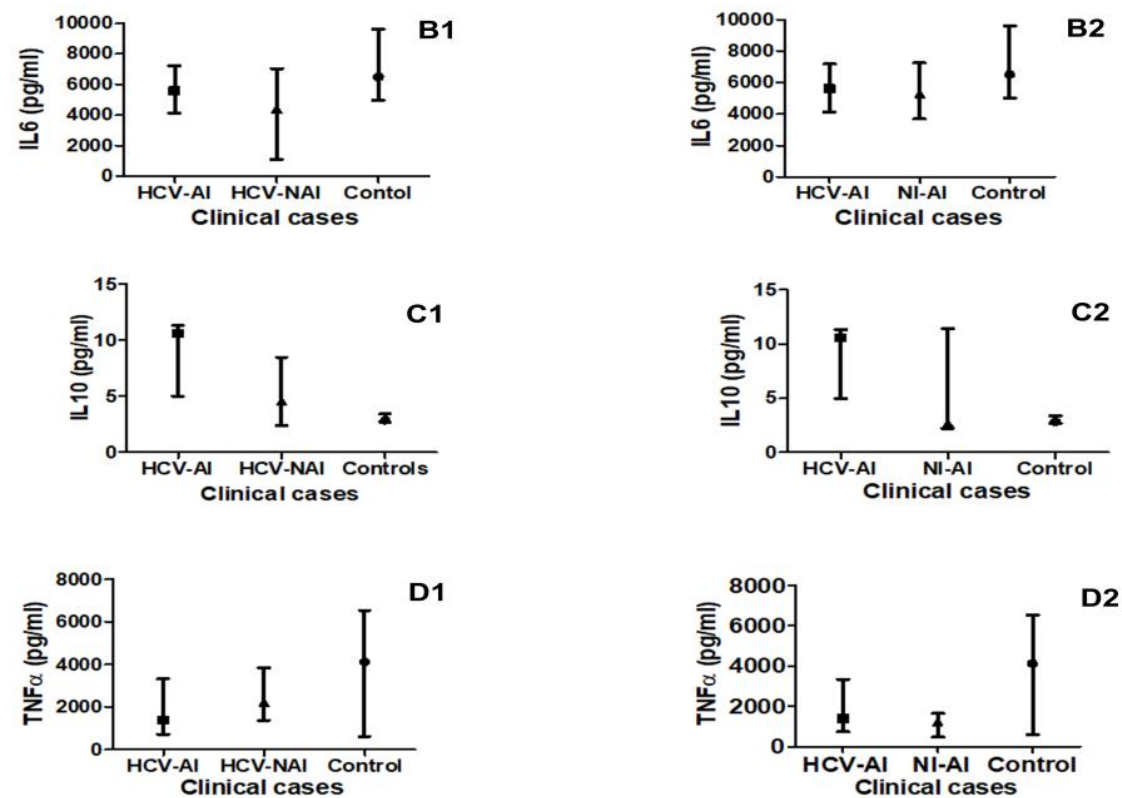

Levels of BAFF/BLyS in human sera were determined using the quantikine human BAFF/BLyS/TNF134B ELISA kit Minneapolis, MN USA). The detected levels were compared to standard recombinant human BAFF/BLyS to enable accurate quantification. The changes in the OD were recorded at $\lambda$-max $450 \mathrm{~nm}$ using a multi-well plate reader.

\section{Statistical analysis}

Statistical analysis and plots were done using the GraphPad PRISM version 5 software. Figures were in box-plot form. The degree of significance was calculated using the unpaired data comparison application (F- test) to compare variances. Differences were considered significant when $P$-values were $<0.05,0.001$, 0.0001; while "ns" means none significant.

\section{Results}

Among the HCV-infected patients the positivity rates of the ANA, AMA ASMA and AGPCA were 12.96, 8.33, 69.44 and $36.11 \%$ respectively (Figure 1 ).

The quantified HCV copy number was significantly lower amongst the autoimmune patients (AI) compared to the non autoimmune individuals (NAI; $P<0.05$; Figure $2 \mathrm{~A}$ ). Although no significant differences were seen in the levels of $\alpha-F P$, GOT and GPT between the two patients' groups the three parameters were respectively $0.87,0.88$ and 0.90 fold higher among the NAI compared to the Al (Figure 2B).
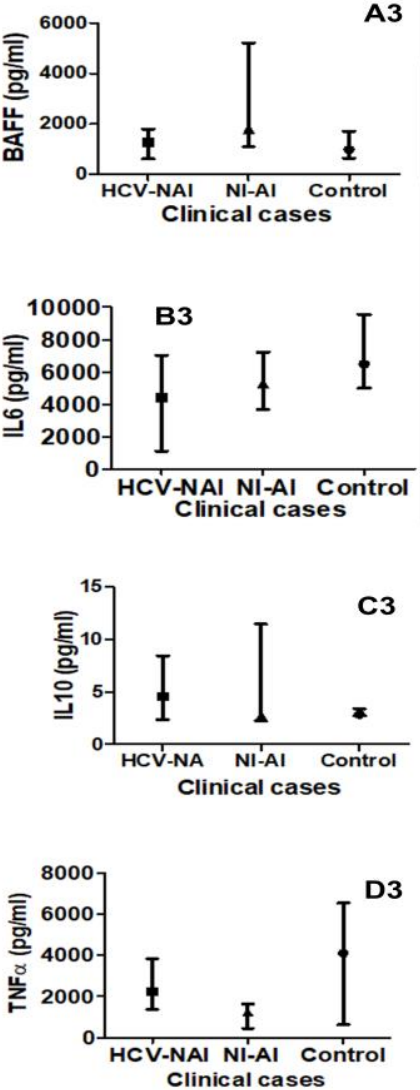

Figure 3. Comparison of B-cell activation factor (BAFF as A1, A2 and A3) and cytokines' profiles (IL-6 as B1, B2 and B3, IL-10 as C1, C2 and C3 and TNF- $\alpha$ as D1, D2 and D3) in HCV-infected-autoimmune (HCV-AI) patients, HCV-infected-non-autoimmune patients (HCV-NAI) patients, HCV-infected-autoimmune (HCV-Al) patients, non-infected-autoimmune patients (NI-AI) patients, and healthy control humans (C). 
The B-cell activation factor (BAFF) level was significantly $(P<0.05)$ higher among the non-infected autoimmune patients (NI$\mathrm{Al}$ ) compared to the $\mathrm{HCV}$-infected non-autoimmune patients (HCVNAl; Figure 3: A1), the HCV-infected autoimmune patients (HCV-Al; Figure 3: $\mathrm{A} 2$ ) and the healthy control humans (C; Figure 3: A1 and A2). Although the HCV-Al showed 1.25 fold higher level than the HCV-NAI the difference was not significant. Also, non-significant higher levels were seen in either of the HCV-Al or HCV-NAl compared to the $C$ and the fold differences were 1.45 and 1.16 , respectively (Figure 3A3).

For the IL6, no significant differences $(P>0.05)$ were seen between various patients' groups. However, the NI-Al showed 0.82 and 0.97 fold higher levels than the HCV-NAl and the HCV-Al, respectively, whereas, the levels were 1.19 fold higher among the HCV-Al compared to the HCV-NAI (Figure 3: B1, B2). Although no significant difference was seen in the cytokine level between all patients' groups and the healthy controls the levels were 0.64 , 0.79 and 0.76 fold higher among the $\mathrm{C}$ compared to HCV-NAI, NI-AI and HCV-Al groups, respectively (Figure 3: B1, B2 and B3).

In case of the IL10, although HCV-Al showed 1.53 fold higher levels than the HCV-NAl the difference was not significant (Figure 3: $\mathrm{C3}$ ); however, its levels were significantly higher $(P<0.05)$ in the HCV-Al, NI-Al and HCV-NAl in comparison to the C (Figure 3: $\mathrm{C} 1, \mathrm{C} 2$ and $\mathrm{C} 3$ ).

Levels of TNF- $\alpha$ were significantly $(P<0.001$ and 0.0001$)$ higher amongst the HCV-NAI and HCV-Al than in the NI-Al patients respectively (Figure 3: D1, D2). Also, levels of the TNF- $\alpha$ were significantly $(P<0.0001)$ higher amongst the $C$ compared to the $\mathrm{NI}$ Al (Figure 3: D2). Levels of TNF- $\alpha$ were not significant amongst the HCV-NAl and HCV-Al patients than in C subjects (Figure 3: D3).

\section{Discussion}

Both HCV persistence [30, 31] and IFN- $\alpha$ therapy [32] trigger autoimmune reactions resulting in production of auto-antibodies such as ANA, [33] AMA, ASMA and AGPCA [34, 7]. In the present study the most reactive autoantibody among Egyptian HCVinfected patients was the ASMA with a recorded prevalence of $69.44 \%$ and approximately similar results were obtained by Clifford et al [35] while, others reported that its reactivity ranged between $12-66 \%$ based on technical reasons and $\backslash$ or differences in the populations investigated [36].

Our results demonstrated that approximately $13 \%$ of $\mathrm{HCV}$ treated Egyptian patients with interferon (DAAS were not available in Egypt at the time of collected samples from 2012 to 2014) were positive for ANA and this agrees with Wilson et al [37] who reported that $4 \%$ to $19 \%$ of patients receiving interferon develop auto-immune disorders and Cassani et al [38] who found that $9 \%$ of $\mathrm{HCV}$ infected patients were positive for ANA. ANA was reported to be a useful candidate biomarker for diagnosing of HCV as it was positive in a big proportion of infected patients [7] and its prevalence in chronic HCV infected humans increased after treatment and this was a possible effect triggered by IFN- $\alpha$ therapy [39].

The previously reported frequency of AMA in autoimmune hepatitis patients varied significantly across different reports and ranged between $5-20 \%$ [40] and our recorder prevalence (8.33\%) of such autoantibody among Egyptian HCV-infected subjects fell within this range.
De Olivera Andrade et al [41] reviewed that the measuring of anti-GPCA level in chronic HCV patients and treated with INF is very important although, the frequency of anti-GPCA are less encountered in HCV infected patients [42]. Our study demonstrated that among Egyptian HCV-infected patients the positive rate of AGPCA autoimmune antibodies was $36.11 \%$. From the results of us and others the frequent association between the four known auto-antibodies with HCV infection/therapy is obvious, yet, one cannot absolutely conclude that the trigger of their production is mainly due to infection and or INF-therapy or due to any other known extrahepatic autoimmune manifestation such as arthralgia, myalgia, rheumatoid arthritis, sicca, lupus erythematosus or vasculitis [43], which complicates identifying the exact source of the detected autoantibody in case of HCV infection.

In our hands the quantified HCV copy number was significantly lower amongst the Al patients compared to the NAl patients and our possible simple explanation of the decreasing HCV load in Al patients could be due to the antiviral capacity of the triggered autoimmune reactions within Al patients' group as autoimmunity is known to involve not only stimulation of auto-antibodies production but also trigger both self-reactive $B$ cells and formation of complement-fixing immune complexes [8]. Along the same lines, HCV in chronically infected patients triggers production of auto-antibodies through expansion of $\mathrm{CD}^{+}$cells and overexpression of CD81 on peripheral B-cells which positively correlate with both cirrhosis and age and can function as helpful markers for diagnosis and treatment of infection [16]. Although the positive correlation between the titers of auto-antibodies with cirrhosis seems to contradict the arrest of the virus propagation by the auto-antibodies, one can postulate that it can reflect both blockage of infection and severe liver inflammation due to the induced autoimmune reactions leading to development of autoimmune hepatitis and ending with cirrhosis.

Our results showed that $\alpha$-FP levels were higher among the HCV-NAl compared to the HCV-Al patients. Wójtowicz-Chomicz et al [44] found that $\alpha$-FP levels frequently increased in patients with chronic HCV even in the absence of HCC and declined during antiviral therapy. Also, $\alpha$-FP concentration was reported to be higher in patients suffering from autoimmune hepatitis Yamagiwa et al [45] or Sjögren's syndrome [46].

Our results showed that levels of GOT and GPT were 0.88 and 0.9 fold higher among the HCV-NAl compared to the HCV-Al patients, respectively. Significantly higher GOT and GPT levels were observed by others in autoimmune hepatitis patients [47] and in a case of polymyositis associated with chronic active hepatitis [48]. In addition, significantly higher GOT levels were found in type 1 diabetics as an example of autoimmune disease [49]. One possible reason why the recorded liver enzymes levels were not significantly higher among the Al in our case is anti-HCV treatment.

The cytokine profile plays an important role in treatment outcome of $\mathrm{HCV}$ infection, and probably modulates the immune response against HCV [50]. Chronic HCV and stages of cirrhosis were associated with misbalance in production of antiinflammatory cytokine [50].

The higher levels of IL6 among the NI-Al compared to the HCV$\mathrm{NAl}$ and the HCV-Al, knowing that all the study subjects in the present report were receiving interferon therapy, these results agree with Freeman et al [51] who reported that interferon Alfa 
and Lambda treatment increased IL- 6 levels in serum of HCVinfected patients. Our results also showed that IL-6 levels were 1.19 fold higher among the HCV-Al compared to the HCV-NAI. Assuming that $\mathrm{Al}$ might correlates with severity of infection, this agrees with previously published report [2] which interestingly described IL- 6 as valuable markers for severity of HCV infection as its serum levels were higher among patients presenting severe infection compared to milder ones.

The recorded higher serum BAFF levels in the present study among the $\mathrm{NI}-\mathrm{Al}$ compared to the HCV-NAI, the HCV-Al and the healthy control humans or among the HCV-Al compared to the HCV-NAl subjects suggest BAFF to be more likely a marker for autoimmunity and not for infection. Tobui et al [52] reported increased serum BAFF levels in patients with chronic $\mathrm{HCV}$, and in patients with HCV-related autoimmunity. On the other hand, Migita et al [53] demonstrated that Serum BAFF levels were elevated in autoimmune hepatitis patients compared with healthy subjects.

The results of the present work showed that both HCV-Al and HCV-NAI patients had significantly higher levels of IL-10 compared to healthy controls which agrees with both Piazzolla et al [50] who showed that serum IL-10 levels were higher among chronic HCV patients compared to controls, and El-Emshaty et al [22] reported the same on Egyptian subjects. Mikadze and Vashakidze [54] reported a significant rise of IL-10 concentration in cases of severe hepatic lesions. Similarly, in our hands levels of TNF- $\alpha$ were higher amongst the HCV-NAl and HCV-Al than in the NI-Al patients and this agreed with reported higher levels of the same cytokine among HCV-infected patients compared to healthy controls [15, 16].

\section{Conclusion}

The obtained results allow the conclusion that both IL6 and BAFF can serve as markers for autoimmunity and/or autoimmunity resulting from severe HCV infection, whereas, IL10 and TNF- $\alpha$ can be considered as markers for HCV infection.

\section{Limitations}

The present study was performed on HCV infected patient's candidates for interferon therapy. Direct acting antiviral for the treatment of HCV-infection (DAAS) were not available in Egypt at the time (2012 to 2014) of collected samples.

\section{Funding}

This study was supported by the awarded grant No. 10010203 from the National Research Center (NRC) of Egypt.

\section{Acknowledgements}

The authors acknowledge the National Research Centre (NRC), Egypt for providing all needed facilities and logistics for the work. This study was supported by the grant from NRC (Project Reference number: 10010203).

\section{Conflict of Interest}

The authors have no conflict of interests related to this publication.

\section{Ethical approval}

All procedures performed in the study were in accordance with the ethical standards of the institution or practice at which the study was conducted. Human blood samples collection were approved by the Medical
Ethical Committee of the National Research Center in Egypt according to the National Institutes of Health in the USA (Project Reference number: 10010203 from the National Research Center of Egypt).

\section{References}

1. Mohamoud YA, Mumtaz GR. The epidemiology of hepatitis C virus in Egypt: a systematic review and data synthesis. BMC Infect Dis 2013; 13: 288. https://doi.org/10.1186/1471-2334-13-288.

2. Nguyen $\mathrm{MH}$, Keeffe EB. Prevalence and treatment of hepatitis $\mathrm{C}$ virus genotypes 4, 5 and 6. Clin Gastroenterol Hepatol 2005; 3 (10 Suppl 2): S97-S101. https://www.ncbi.nlm.nih.gov/pubmed/16234071.

3. Abdel-Ghaffar TY, Sira MM, El Naghi S. Hepatitis C genotype 4: The past, present, and future. World J Hepatol 2015; 7(28): 2792-2810. https://doi.org/10.4254/wjh.v7.i28.2792.

4. Kandeel A, Genedy M, El-Refai S, Funk AL, Fontanet A, Talaat M. The prevalence of hepatitis C virus infection in Egypt 2015: implications for future policy on prevention and treatment. Liver Int 2017; 37(1): 4553. https://doi.org/10.1111/liv.13186.

5. Bahgat $M$, Emam M, Refaey MM, Abd-Eldayem WA, Emara MW, Hosam I et al. Study of auto-antibodies in Egyptian non-B, non-C chronic hepatitis patients. Afro-Egyptian J Inf End Dis 2011; 1(1): 1-8. https://doi.org/10.21608/AEJI.2011.8753.

6. Cacoub P, Poynard T, Ghillani P, Charlotte F, Olivi M, Piette JC, et al. Extrahepatic manifestations of chronic hepatitis C. Multivir C group. Multi-department virus C. Arthritis Rheum 1999; 42(10): 2204-2212. https://doi.org/10.1002/1529-0131(199910)42:10<2204::AIDANR24>3.0.CO;2-D.

7. Cacoub P, Renou C, Rosenthal E, Cohen P, Loury I, Loustaud-Ratti V, et al. Extrahepatic manifestation association with $C$ virus infection. A prospective multicentre study of 321 patients. The Germivic. Groupe d'Etude et de Recherche en Medecine Interne et Maladies Infectieuses sur le Virus de I'Hepatite C. Medicine (Baltimore) 2000; 79(1): 47-56 https://doi.org/10.1097/00005792-200001000-00005.

8. Blank M, Shoenfeld Y. B cell targeted therapy in autoimmunity. $J$ Autoimmun 2007; 28(2-3): 62-68. https://doi.org/10.1016/j.jaut.2007.02.001.

9. Flores-Chávez A, Carrion JA, Forns X, Ramos-Casals M. Extrahepatic manifestations associated with Chronic Hepatitis C Virus Infection. Rev Esp Sanid Penit 2017; 19(3): 87-97. https://doi.org/10.4321/S157506202017000300004.

10. De Vita S, De Re V, Sansonno D, Sorrentino D, Corte RL, Barbar P, et al. Gastric mucosa as an additional extrahepatic localization of hepatitis $C$ virus: viral detection in gastric low-grade lymphoma associated with autoimmune disease and in chronic gastritis. Hepatology 2000; 31(1): 182-189 https://doi.org/10.1002/hep.510310127.

11. Söderlin MK, Kautiainen H, Skogh T, Leirisalo-Repo M. Quality of life and economic burden of illness in very early arthritis. A population based study in southern Sweden. J Rheumatol 2004; 31(9): 1717-1722. https://www.ncbi.nlm.nih.gov/pubmed/15338489.

12. Soltesz G, Patterson C, Dahlquist G. Global trends in childhood type 1 diabetes. In: International Diabetes Federation (IDF) diabetes Atlas, 3th ed. International Diabetes Federation, 2006: 151-191. https://idf.org/component/attachments/attachments.html?id=810\&ta sk=download.

13. Buskila D. Hepatitis C-associated rheumatic disorders. Rheum Dis Clin North Am 2009; 35(1): 111-123. https://doi.org/10.1016/j.rdc.2009.03.005.

14. Wu CH, Xu XY, Tian GS, Yu YY. Serum autoantibodies of patients with chronic hepatitis $C$ and the significance there of in infection of hepatitis C virus. Zhonghua Yi Xue Za Zhi 2006; 86(6): 390-393. Chinese. https://www.ncbi.nlm.nih.gov/pubmed/16677548.

15. Tarragô AM, da Costa AG, Pimentel JP, Gomes ST, Freitas FB, Lalwani P, et al. Combined impact of hepatitis $C$ virus genotype 1 and interleukin6 and tumor necrosis factor- $\alpha$ polymorphisms on serum levels of proinflammatory cytokines in Brazilian HCV-infected patients. Hum 


\section{Immunol 2014; 75(1):}

https://doi.org/10.1016/j.humimm.2014.08.198.

16. Antonelli A, Ferri C, Ferrari SM, Ghiri E, Goglia F, Pampana A, et al. Serum levels of pro-inflammatory cytokines interleukin-1beta, interleukin-6, and tumor necrosis factor alpha in mixed cryoglobulinemia. Arthritis Rheum 2009; 60(12): 3841-3847. https://doi.org/10.1002/art.25003.

17. Świdrowska-Jaros J, Orczyk K. Smolewska E. Macrophages silent enemies in juvenile idiopathic arthritis. Postepy Hig Med Dosw (Online) 2016; 70: 743-750. https://doi.org/10.5604/17322693.1208887.

18. Signorelli SS, Candido S, Salemi R, Fiore V, Mangiafico M, Libra M. Low levels of inflammation and the absence of subclinical atherosclerosis in rheumatoid arthritis. Mol Med Rep 2016; 13(4): 3521-1524. https://doi.org/10.3892/mmr.2016.4962.

19. Neuman MG, Sha K, Esguerra R, Zakhari S, Winkler RE, Hilzenrat N, et al. Inflammation and repair in viral hepatitis C. Dig Dis Sci 2008; 53(6): 1468-1487. https://doi.org/10.1007/s10620-007-0047-3.

20. Shah $S, M a Y$, Scherzer $R$, Huhn $G$, French $A L$, Plankey $M$, et al. Association of HIV, hepatitis $C$ virus and liver fibrosis severity with interleukin-6 and C-reactive protein levels. AIDS 2015; 29(11): 13251333. https://doi.org/10.1097/QAD.0000000000000654.

21. Zhang L, Hao CQ, Miao L, Dou XG. Role of Th1/Th2 cytokines in serum on the pathogenesis of chronic hepatitis $\mathrm{C}$ and the outcome of interferon therapy. Genet Mol Res 2014; 13(4): 9747-9755. https://doi.org/10.4238/2014.

22. El-Emshaty HM, Nasif WA, Mohamed IE. Serum Cytokine of IL-10 and IL-12 in Chronic Liver Disease: The Immune and Inflammatory Response. Dis Markers 2015; 2015: 707254. https://doi.org/10.1155/2015/707254.

23. Krivosikova M, Dallos T, Maslinski W, Buc M. B cell activating factor, its role in autoimmunity, and targeting in autoimmune disease. Bratis/ Lek Listy 2009; 110(3): 137-145. https://www.ncbi.nlm.nih.gov/pubmed/19507632.

24. Gheita TA, Bassyouni IH, Emad Y, el-Din AM, Abdel-Rasheed E, Hussein H. Elevated BAFF (BLyS) and APRIL in Juvenile idiopathic arthritis patients: relation to clinical manifestations and disease activity. Joint Bone Spine 2012; 285-290. https://doi.org/10.1016/j.jbspin.2011.05.020.

25. Lake-Bakaar G, Jacobson I, Talal A. B cell activating factor (BAFF) in the natural history of chronic hepatitis $C$ virus liver disease and mixed cryoglobulinaemia. Clin Exp Immunol 2012; 170(2): 231-237. https://doi.org/10.1111/j.1365-2249.2012.04653.x.

26. Ayad MW, Elbanna AA, Elneily DA, Sakr AS. Association of BAFF $871 \mathrm{C} / \mathrm{T}$ promoter polymorphism with hepatitis C-related mixed cryoglobulinemia in a Cohort of Egyptian patients. Mol Diagn Ther 2015; 19(2): 99-106. https://doi.org/10.1007/s40291-015-0134-7.

27. Barros PO, Cassano T, Hygino J, Ferreira TB, Centurião N, Kasahara TM, et al. Prediction of disease severity in neuromyelitis optica by the levels of interleukin (IL)- 6 produced during remission phase. Clin Exp Immunol 2016; 183(3): 480-489. https://doi.org/10.1111/cei.12733.

28. El-Serag HB, Hampel H, Yeh C, Rabeneck L. Extrahepatic manifestations of hepatitis C among United States male veterans. Hepatology 2002; 36(6): 1439-1445. https://doi.org/10.1053/jhep.2002.37191.

29. Leckie G, Schneider G, Abravaya K, Hoenle R, Johanson J, Lampinen J, et al. Performance attributes of the LCx HCV RNA quantitative assay. $J$ Virol Meth 2004; 207-215. https://www.ncbi.nlm.nih.gov/pubmed/14667537.

30. Jadali Z, Alavian SM. Autoimmune diseases co-existing with hepatitis C virus Infection. Iran J Allergy Asthma Immunol 2010; 9(4): 191-204. https://doi.org/09.04/ijaai.191206.

31. Bridge SH, Pagano S, Jones M, Foster GR, Neely D, Vuilleumier N, et al. Autoantibody to apolipoprotein A-1 in hepatitis $\mathrm{C}$ virus infection: a role in atherosclerosis? Hepatol Int 2018; 12(1): 17-25. https://doi.org/10.1007/s12072-018-9842-5.
32. Berggren O, Hagberg N, Weber G, Alm GV, Rönnblom L, Eloranta ML. B lymphocytes enhance interferon- $\alpha$ production by plasmacytoid dendritic cells. Arthritis Rheum 2012; 64(10): 3409-3419. https://doi.org/10.1002/art.34599.

33. Wan L, Zhu H, Gu Y, Liu H. Diagnostic value of trait antinuclear antibodies and multiple immunoglobulin production in autoimmune diseases. J Clin Lab Anal 2018; 32(4): e22361. https://doi.org/10.1002/jcla.22361.

34. Zuckerman E, Zuckerman T, Levine AM, Douer D, Gutekunst K, Mizokami $\mathrm{M}$, et al. Hepatitis $\mathrm{C}$ virus infection in patients with B-cell non-Hodgkin lymphoma. Ann Intern Med 1997; 127(6): 423-428. https://doi.org/10.7326/0003-4819-127-6-199709150-00002.

35. Clifford BD, Donahue D, Smith L, Cable E, Luttig B, Manns M, et al. High prevalence of serological markers of autoimmunity in patients with chronic hepatitis C. Hepatology 1995; 21(3): 613-619. https://www.ncbi.nlm.nih.gov/pubmed/7533120.

36. Gregorio GV, Pensati $P$, lorio $R$, Vegnente $A$, Mieli-Vergani $G$, Vergani D. Autoantidody prevalence in children with liver disease due to chronic hepatitis V virus (HCV) infection. Clin Exp Immunol 1998; 112(3): 471-476. https://www.ncbi.nlm.nih.gov/pubmed/9649217.

37. Wilson LE, Widman D, Dikman SH, Gorevic PD. Autoimmune disease complicating antiviral therapy for hepatitis $C$ virus infection. Semin Arthritis Rheum 2002; 32(3): 163-173. https://doi.org/10.1053/sarh.2002.37277.

38. Cassani F, Bianchi FB, Lenzi M, Volta U, Pisi E. Immunomorphological characterization of antinuclear antibodies in chronic disease. J Clin Pathol 1985; 38(7): 801-805. https://doi.org/10.1136/jcp.38.7.801.

39. Preziati D, La Rosa L, Covini G, Marcelli R, Rescalli S, Persani L, et al. Autoimmunity and thyroid function in patients with chronic active hepatitis treated with recombinant interferon alpha-2a. Eur J Endocrinol 1995; 132(5): 587-593. PMID: 7749499

40. Floreani A, Baragiotta A, Leone M G, Baldo V, Naccarato R. Primary biliary cirrohosis and hepatitis C virus infection. Am J Gastroenterol 2003; 98 2757-2762. https://www.ncbi.nlm.nih.gov/pubmed/7749499.

41. Andrade LJ, Atta AM, Atta ML, Silva CA, Junior DA, Parana R. Immune response in hepatitis C. Rev Panam Infectol 2010; 12: 31-36. https://pdfs.semanticscholar.org/f5da/f4c61ad88bc1f8bb1df60eadd6 $63 c 815 d 4 d 7 . p d f$.

42. Fabbri C, Jaboli MF, Giovanelli S, Azzaroli F, Pezzoli A, Accogli E, et al. Gastric autoimmune disorders in patients with chronic hepatitis $C$ before, during and after interferon-alpha therapy. Word J Gastroenterol 2003; 9(7): 1487-1490. https://doi.org/10.3748/wjg.v9.i7.1487.

43. Sayiner ZA, Haque U, Malik MU, Gurakar A. Hepatitis C virus infection and its rheumatologic implications. Gastroenterol Hepatol (N Y) 2014; 10(5): 287-293. https://www.ncbi.nlm.nih.gov/pubmed/24987312.

44. Wójtowicz-Chomicz K, Cichoz-Lach H, Lis E, Kowalik A, Słomka M. Evaluation of alpha-fetoprotein concentration in patients with chronic liver diseases. Pol Merkur Lekarski 2012; 32(192): 374-377. Polish. https://www.ncbi.nlm.nih.gov/pubmed/22891562.

45. Yamagiwa S, Tamura Y, Takamura M, Genda T, Ichida T, Ishikawa T, et al. Increase of fucosylated alpha-fetoprotein fraction at the onset of autoimmune hepatitis and acute liver failure. Hepatol Res 2014; 44(14): E368-375. https://doi.org/10.1111/hepr.12318.

46. Ye $L$, Wang ZY, Zhang X. Sjögren's syndrome with extremely elevated plasma alpha-fetoprotein that responded to immunosuppressant treatment. Chin Med J (Engl) 2012; 125(21): 3916-3917. https://www.ncbi.nlm.nih.gov/pubmed/23106900.

47. Musch E, Chrissafidou A, Malek M. Acute hepatitis due to kava-kava and St John's Wort: an immune-mediated mechanism. Dtsch Med Wochenschr 2006; 131(21): 1214-1217. German. https://doi.org/10.1055/s-2006-941754.

48. Fujitake J, Saida K, Nishitani H, Suginoshita T, Osaki S. A case of polymyositis associated with chronic active hepatitis. Rinsho 
Shinkeigaku 1990; 30(1): 55-61. Japanese. https://www.ncbi.nlm.nih.gov/pubmed/2184964.

49. Verma M, Metgud R, Madhusudan AS, Verma N, Saxena M, Soni A. A comparative study of glutamate oxaloacetate transaminase (GOT) and glutamate pyruvate transaminase (GPT) levels in the saliva of diabetic and normal patients. Biotech Histochem 2014; 89(7): 529-534. https://doi.org/10.3109/10520295.2014.905705.

50. Piazzolla G, Tortorella C, Schiraldi O, Antonaci S. Relationship between interferon gamma, interleukin-10, and interleukin-12 production in chronic hepatitis $\mathrm{C}$ and in vitro effects of interferon-alpha. J Clin Immunol 2000; 20(1): 54-61. https://www.ncbi.nlm.nih.gov/pubmed/10798608.

51. Freeman J, Baglino S, Friborg J, Kraft Z, Gray T, Hill M, et al. Pegylated interferons Lambda-1a and alfa-2a display different gene induction and cytokine and chemokine release profiles in whole blood, human hepatocytes and peripheral blood mononuclear cells. J Viral Hepat 2014; 21(6): e1-9. https://doi.org/10.1111/jvh.12243.

52. Toubi E, Gordon S, Kessel A, Rosner I, Rozenbaum M, Shoenfeld Y, et al. Elevated serum B-lymphocyte activating factor (BAFF) in chronic hepatitis C virus infection: Association with autoimmunity. J Autoimmun 2006; 27(2): 134-139. https://doi.org/10.1016/i.jaut.2006.07.005.

53. Migita K, Abiru S, Maeda $Y$, Nakamura $M$, Komori $A$, Ito $M$, et al. Elevated serum BAFF levels in patients with autoimmune hepatitis. Hum Immunol 2007; 68(7): 586-591. https://doi.org/10.1016/j.humimm.2007.03.010.

54. Mikadze I, Vashakidze E. The role of interleukin-10 in patients with HCV infection. Georgian Med News 2012; (207): 30-33. https://www.ncbi.nlm.nih.gov/pubmed/22859446.

Authors:

Amany S. Maghraby - PhD, Professor, Department of Therapeutic Chemistry, Division of Pharmaceutical and Drug Industries Research and Research Group Immune- and Bio-markers for Infection, the Centre of Excellence for Advanced Sciences, the National Research Centre, Cairo, Egypt. https://orcid.org/0000-0002-9723-5011.

Solaf A. Kamel - PhD, Professor, Department of Clinical and Chemical Pathology, the National Research Center, Cairo, Egypt. https://orcid.org/0000-0002-9342-3672.

Dalia B. Fayed - PhD, Researcher, Department of Therapeutic Chemistry, Division of Pharmaceutical and Drug Industries Research, the National Research Centre, Cairo, Egypt. https://orcid.org/0000-0001-5238-7516.

Heba Shawky - PhD, Researcher, Department of Therapeutic Chemistry, Division of Pharmaceutical and Drug Industries Research, the National Research Centre, Cairo, Egypt. https://orcid.org/0000-0001-8403-1143.

Mona A. Razin - MSc, Researcher Assistant, Department of Therapeutic Chemistry, Division of Pharmaceutical and Drug Industries Research, the Centre of Excellence for Advanced Sciences, the National Research Centre, Cairo, Egypt. https://orcid.org/0000-0003-1900-6632.

Rola N. Abd-Elshafy - MSc, Researcher Assistant, Department of Therapeutic Chemistry, Division of Pharmaceutical and Drug Industries Research and Research Group Immune- and Bio-markers for Infection, the Centre of Excellence for Advanced Sciences, the National Research Centre, Cairo, Egypt. https://orcid.org/0000-0002-2777-2487.

Azza F Arafa - PhD, Assistant Professor, Department of Therapeutic Chemistry, Division of Pharmaceutical and Drug Industries Research, the National Research Centre, Cairo, Egypt. https://orcid.org/0000-0001-7729$\underline{24874 .}$.

Dina N. Abd-Elshafy - PhD, Assistant Professor, Department of Water Pollution Research, Environmental Research Division and Research Group Immune- and Bio-markers for Infection, the Centre of Excellence for Advanced Sciences, the National Research Centre, Cairo, Egypt. https://orcid.org/0000-0002-2777-2487.

Mahmoud M. Bahgat - PhD, Professor, Department of Therapeutic Chemistry, Division of Pharmaceutical and Drug Industries Research and Research Group Immune- and Bio-markers for Infection, the Centre of
Excellence for Advanced Sciences, the National Research Centre, Cairo, Egypt. https://orcid.org/0000-0002-6485-8722. 